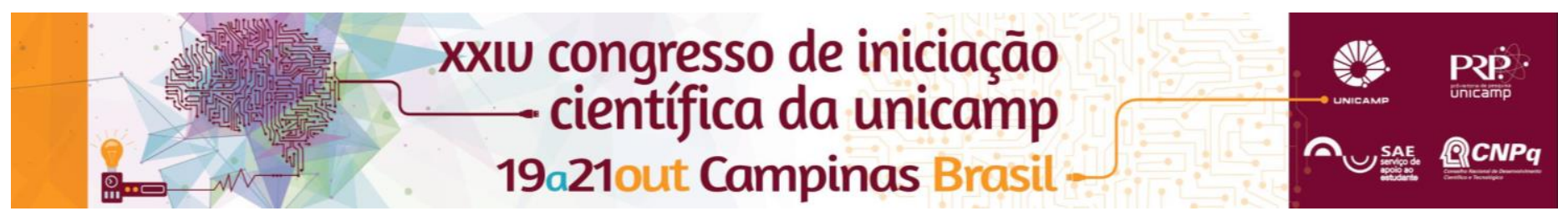

\title{
Desempenho de vermifiltro e avaliação da dinâmica populacional de minhocas no tratamento de esgoto.
}

\author{
Adzania. F. Leopoldino* (IC), Jonas. H. Oliveira (IC), Francisco. J.P. L. Madrid (PG), Jerusa Schneider (PQ).
}

\section{Resumo}

O presente estudo avaliou o desempenho de bioifiltros colonizados com minhocas na camada superior aplicados no tratamento de esgoto bruto, analisando-se a influência de diferentes composições do substrato dessa camada. Mensalmente foi feita a caracterização visual e físico-química do líquido drenado. Os resultados mostram que os vermifiltros compostos por braquiária apresentam maior retenção do efluente e melhor qualidade do lixiviado do que o tratamento com solo puro. Os biofiltros contendo minhocas apresentaram maior concentração de turbidez do que as unidades de controle sem minhocas.

\section{Palavras-chave:}

Sistema de tratamento de esgoto, vermifiltração, Eisenia andrei.

\section{Introdução}

Os vermifiltros são filtros de tratamentos de efluentes biológicos, constituído por câmara única, uma camada superior de substrato com material orgânico e minhocas de espécies epigéicas e detritívoras normalmente utilizadas em processos de vermicompostagem. Nesse sentido, este trabalho teve como objetivo avaliar o desempenho do sistema de vermifiltros colonizados na camada de solo com minhocas (Oligochaeta da espécie Eisenia andrei), analisando a influência de diferentes substratos (camada superior de solo com material orgânico e minhocas) na eficiência do processo de vermifiltração.

\section{Resultados e Discussão}

Os vermifiltros foram construídos em garrafas pet de $1,5 \mathrm{~L}$, onde foram colocados aproximadamente $5 \mathrm{~cm}$ de brita 1 e os diferentes tipos de substratos estudados: 1) Solo- somente solo; 2) SA-Solo + Areia; 3) SB- Solo + Braquiária; 4) SBM- Solo + Braquiária moída; 5) ABMAreia + Braquiária moída. Cada vermifitro foi colocado dez minhocas $(\mathrm{c} / \mathrm{m})$ conduzido com um controle em paralelo, com as mesmas camadas, mas sem minhocas $(\mathrm{s} / \mathrm{m})$, totalizando 10 tratamentos com três repetições.

O esgoto bruto (EB) foi aplicado de segunda a sexta, e a cada 15 dias foram tiradas as fotos, e mensalmente feito a coleta das amostras para caracterização físico-químico. Para análise do liquido percolado, os parâmetros físicoquímicos utilizados foram: alcalinidade total, condutividade, turbidez e pH. No caso, seguiu-se a metodologia padronizada por APHA et al.

Como pode ser visualizado na Figura $1 \mathrm{~A}$, os resultados mostram que os vermifiltros com braquiária apresentaram maior retenção do efluente nos sistemas e melhor qualidade do lixiviado do que o tratamento com solo. Os tratamentos contendo minhocas apresentaram maior concentração de turbidez do que sem minhocas (Figura 2B). $\mathrm{Na}$ avaliação do líquido percolado, o pH variou de 7,1 a 7,8 e não houve muita variação na faixa de $\mathrm{pH}$ nos diferentes tratamentos, turbidez no solo puro apresentou maior concentração que os demais tratamentos. Alcalinidade e condutividade tiveram variações em diferentes tratamentos (Figura $2 \mathrm{~B}$ ).

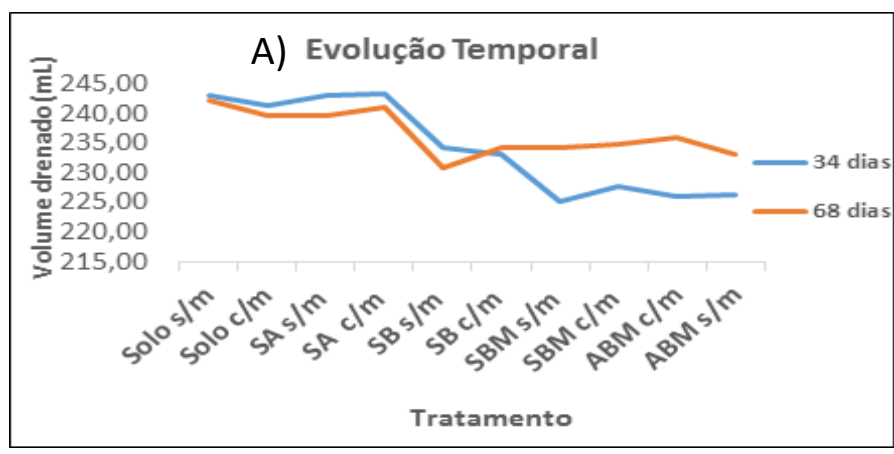

B) Análise do lixiviado

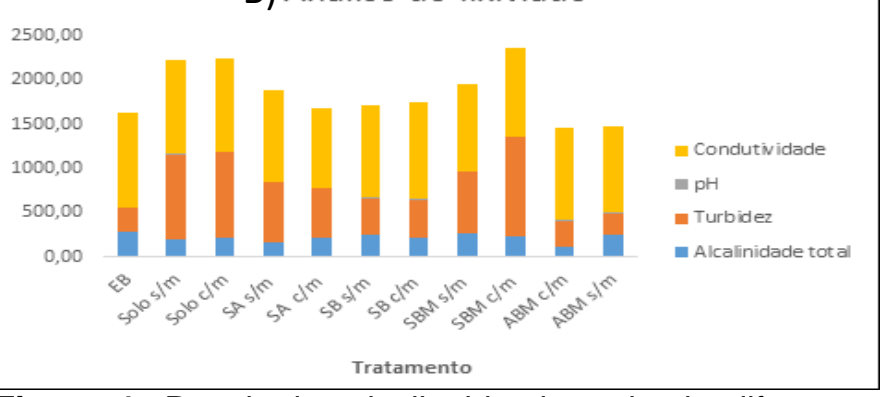

Figura 1. Resultados do liquido drenado de diferentes substratos. A) Volume drenado dos vermifiltros em função do tempo; B) Caracterização físico-química do líquido percolado dos vermifiltros.

\section{Conclusões}

Pode-se concluir que os tratamentos com braquiária mostraram maior eficiência do que com solo, as minhocas desenvolveram melhor no meio com braquiária.

\section{Agradecimentos}

Ao CNPQ por fomentar esta pesquisa.

1. American Public Health Association AWWA. Standard methods for the examination of water and wastewater. Washington, DC; 2012.

2. Madrid, F. J. P. L. Aplicação da vermifiltração no tratamento de esgoto sanitário. 2016. Disertação (Mestrado em Engenharia Civil) -Faculdade de Engenharia Civil Arquitetura e Urbanismo, Universidade Estadual de Campinas. 